\title{
De Angola à contracosta, um relato de viagem ao serviço do (auto)conhecimento
}

\author{
Dina Chora ${ }^{1}$
}

RESUMO: Partindo da obra De Angola à contracosta, este ensaio pretende analisar as interferências do quadro normativo do pensamento europeu nas descrições e relatos sobre o negro e seus costumes e verificar se a vivência e a experienciação in loco podem alterar a maneira de ver e compreender o "outro".

ABSTRACT: Using De Angola à contracosta as a case study, this essay aims the analysis of the interferences of the regulatory framework of the European thought in the descriptions and tales about the black people and their customs, and also to assess if living and experiencing in loco may change the way we see and understand the "other".

PALAVRAS-CHAVE: Etnocentrismo; Alteridade; Autoconhecimento; Experienciação KEYWORDS: Ethnocentrism; alterity; Self-knowledge; Experiential learning

As naturezas dos homens são parecidas; são seus hábitos que os afastam uns dos outros.

Confúcio, Anacleta

Só conhecemos os homens quando conhecemos os critérios de valoração a que eles obedecem; é destes que dependem, [...] o seu carácter e o seu comportamento em face das situações da vida.

Mas precisamente para podermos apreciar as valorações dos outros, é preciso possuirmos [...] um conhecimento profundo e largo dos nossos próprios valores e da sua escala.

Johannes Hessen, Filosofia dos valores

1 Mestre em Estudos Românicos, especialização em Literaturas Africanas de Língua Portuguesa e, actualmente, doutoranda na Faculdade de Letras da Universidade de Lisboa, na área da Literatura Brasileira. 


\section{Introdução}

De Angola à contracosta ${ }^{2}$ é o relato da segunda viagem de exploração de Brito Capelo e Roberto Ivens ao continente africano, sob a égide da Comissão Nacional Portuguesa de Exploração e Civilização da África, criada pela Sociedade de Geografia de Lisboa, fundada em 1875, promotora de actividades que defendessem os dominios portugueses em África.

Se, na primeira expedição, os dois oficiais da marinha tinham por missão o reconhecimento científico de Benguela até às terras de Iaca, na segunda, matéria do corpus literário desta análise, pretendiam descobrir um caminho comercial que ligasse Angola a Moçambique e elaborar a cartografia das regiões desconhecidas até então, respondendo, por conseguinte, a interesses nacionais. A viagem teve início no dia 6 de Janeiro de 1884 e terminou a 20 de Setembro de 1885, tendo os expedicionários sido recebidos em Portugal, em apoteose, pelo rei D. Luís. ${ }^{3}$

Constituída por dois volumes, esta obra é muito mais do que um texto de cariz pragmático, cartográfico ou instrutivo. Nela estão registados dados geográfico-naturais, etnográficos, linguísticos, reflexões pessoais, conselhos úteis a quem projecte pôr em marcha viagens similares ${ }^{4}$, acontecimentos, por vezes narrados em segundamão, com a principal função de exemplificar uma característica de uma personagem, contextualizar a ação central que então ocupa o narrador ou, simplesmente, quebrar a monotonia do relato, enquanto distração ${ }^{5}$, como se nos afigura ser o episódio da personagem Trinta e das suas duas mulheres (I, p. 193-194). Dito por outras palavras, a par com os

\footnotetext{
2 Utiliza-se a edição das Publicações Europa-América, de Maio de 1998, volumes I e II. As referências ao corpus serão anotadas por um número romano que corresponde ao volume, seguido da indicação da(s) página(s).

${ }^{3} \mathrm{~A}$ quem foi dedicado o livro.

${ }^{4}$ Referem-se, a título de exemplo, as páginas 46-50 do volume II, onde o narrador dá indicações precisas para se sobreviver em África.

5"les digressions sont souvent justifiées: d'abord elles offrent une distraction au lecteur. Ensuite elles s'imposent d'elles-mêmes, par association d'idées, en raison de leur opportunité". Odile Gannier, La littérature de voyage, p. 42.
} 
registos de ordem cientifica, nela se encontram as aventuras e as desventuras de dois portugueses que, com os seus homens e em caravana, se arriscaram por terras, até então, pouco ou nada desbravadas. É “a história de uma peregrinação, modelada passo a passo nos apontamentos do respectivo diário" (I, p. 23) e que terá

a tarefa pouco fácil [...] de pegar-vos [ao leitor] pela mão, e conduzir-vos passo a passo nessa tortuosa vereda por nós trilhada, [...] de patentear-vos enfim todos os sofrimentos, fadigas, fomes, chuvas, angústias e mortes que nos serviram de lúgubre cortejo desde o mar Atlântico até ao Índico! (I, p. 25)

Assim, o narrador, tal como Garrett, propõe-se a que "de quanto vir e ouvir, de quanto [...] pensar e sentir se há-de fazer crónica."6

Fica, do exposto, que esta obra pode ser analisada de diferentes ângulos $^{7}$ por diversas áreas do saber. Não entrando em problematizações sobre o conceito de "literatura de viagens", julgamos ser pacífico incluí-la neste subgénero narrativo, dado que nela se acham características distintivas normalmente aduzidas a esta tipologia de textos: uma preocupação literária, a promoção do prazer de ler, um cunho testemunhal, o que explica o projeto de dizer a verdade, de ser verosimil, (com recurso a vocábulos locais, croquis) ${ }^{8}$, o uso de abundantes descrições pormenorizadas, uma estrutura narrativa fechada (relato completo de uma viagem que durou um ano e oito meses) narrada na primeira pessoa (Nós inclusivo) o que transforma o discurso numa experiência pessoal. Nela também se dá destaque às similitudes e dissemelhanças entre aquele espaço físico e humano (o outro, o lá) e o do narrador que conta com um leitor compreensivo já que partilham a mesma realidade cultural e o mesmo espaço - o cá - a Europa 9 .

\footnotetext{
${ }^{6}$ A. Garrett, Viagens na minha terra, p.15.

7 Veja-se o artigo de Alberto Carvalho no qual se faz uma análise minuciosa e abrangente da obra.

8 "Le récit de voyage s'accompagne d'illustrations, croquis, gravures, photographies, mais aussi de cartes, qui ponctuent et actualisent l'itinéraire" - Odile Gannier, idem, p.64.

9 "Le récit de voyage est un genre dans lequel la personnalité de l'auteur est présente et prépondérante. Il apparaît comme organisateur du récit, commentateur, garant de
} 
Com este trabalho deter-nos-emos nas descrições que o narradorviajante faz das paisagens humanas que vai encontrando, para assim avaliar o olhar do homem branco face ao homem africano, uma vez que, relatar costumes e usos de seres com praxis e éticas diferentes, coloca o problema da interpretação e do julgamento do sujeito/relator, cujo pensamento se edifica com base na hierarquia de valores pré-existentes e normativos da sua sociedade ${ }^{10}$. Tal como afirma Todorov, "Ce que nous jugeons ridicule chez l'autre n'est que ce qui nous est étranger" 11. Parece-lhe natural que se tenha grande estima pela própria cultura e modus operandi, o que induz naturalmente a uma atitude egocêntrica e etnocêntrica face ao outro. Desta forma não se produz um relato objectivo e imparcial sobre o que é estranho, conservando-se uma distanciação instigada pela noção de civilidade e pirâmide valorativa/ética impostas pela sociedade à qual o relator pertence.

É nosso intento averiguar se essa visão se transforma à medida que a viagem progride e, neste caso, apurar os motivos que levam a essa mudança. Partindo da expressão “peregrinação” (p. 23), analisaremos o modo como o narrador-peregrino (na acepção de estranho, estrangeiro) se relaciona com o autóctone e como o retrata. Implicitamente colocar-se-á a problemática da alteridade, da relação do eu com o outro e a questão de serem reciprocamente estranhos. Assim, além de se pretender averiguar em que medida o etnocentrismo, os preconceitos, os clichés e os estereótipos têm a sua marca nas descrições dos nativos, avaliaremos também se compreender/conhecer o outro, através da convivência e experiência, modifica o eu, em termos de conformação perceptiva de si próprio, dos outros e da aceitação da pluralidade de seres, de culturas, de estruturas éticas, morais, religiosas,... Se, em cada um de nós, o social existe em surdina,

sa véracité. En effet, il doit assumer deux types de discours bien différents: évoquer une expérience individuelle et rendre compte d'une réalité objective extérieure. Il doit en outre maintenir ouvert le dialogue avec le lecteur, pour l'assurer qu'il s'acquitte bien de ces deux tâches". Odile Gannier Id., p. 51.

10Odile Gannier Id., p. 71-74.

11 Tzvetan Todorov, Nous et les Autres: La Réflexion Française sur la Diversité Humaine, p.66. 
transportamo-lo sem que tenhamos, por vezes, consciência, mas isto funciona como estímulo às nossas reacções. ${ }^{12}$ Concludentemente, a apreciação que o sujeito-eu_faz do objecto-tu informa não sobre este, mas sobre si próprio, por ausência de aproximação do eu que observa ao tu observado ${ }^{13}$.

Impõe-se-nos reflectir igualmente sobre a aplicabilidade do conceito de intersubjectividade ${ }^{14}$ ao texto em análise. Implicando uma pluralidade de sujeitos (pelo menos dois) que se relacionam e cooperam (nós), desta troca, resultará um enriquecimento bilateral. Por conseguinte, o reconhecimento da alteridade é condição sine qua non para o autoconhecimento pois o eu só existe em correlação a um tu e só se conhece quando se confronta com o outro - ou por similitude ou por contraste. Procuraremos verificar se a tomada de consciência das diferenças, leva o narrador a questionar os seus próprios códigos culturais e a relativizá-los, se adquire a capacidade de se descentralizar no processo do conhecimento de forma a apreender as noções de diferente e de relatividade.

\section{As primeiras impressões - o que se diz dos Homens}

Após um capítulo dedicado às relações históricas entre Portugal e África (I, p.29-40), inicia-se o relato da viagem com a anotação precisa do seu dia, hora e local (“6 de Janeiro do ano do Senhor de 1884, pelas nove horas da manhã, achávamo-nos a bordo do vapor S. Tomé, [...], prontos a abalar", I, p. 41-42). Um pouco mais adiante, o narrador informa que os trabalhos da expedição se iniciaram em Março de 1884 e apresenta os objectivos da mesma (I, p. 66) ${ }^{15}$. Desde logo se verifica a natureza heteróclita da obra, pois o relato é sistematicamente

\footnotetext{
12 Merleau-Ponty, "Autrui et le Monde Humain".

${ }^{13}$ Tzvetan Todorov, idem, p. 28.

${ }^{14}$ Dominique Groux et Louis Porcher, L'Altérité, p. 137, 209-210.

15 “o nosso plano era principalmente estudar e esclarecer em definitivo toda a zona central da nossa província angolo-moçambicana, calculando até que ponto os férteis sertões que a constituem poderiam encontrar no Zambeze uma saída para os seus produtos" (I, p.66).
} 
interrompido pela indexação de diversas reflexões, como o atesta o excerto sobre a região do Congo:

[esses homens] tentaram levar a civilização ao âmago do continente, e afinal de tamanho afã apenas haviam ficado os traços nessa ingrata terra, verdadeira madrasta do Branco, porque então como hoje também está sucedendo, se persuadiu o Europeu que com a sua enérgica força podia desbravar e exercer domínio sobre selvas e negraria, sem reflectir que acima de tudo ditava a lei o clima, ao qual a constituição física era difícil que resistisse. - Hoje como então, esta é a verdade. (I, p.44)

Note-se que o narrador se apoia aqui num testemunho anterior e alheio (o do cônsul americano W. P. Tisdel) o que, do ponto de vista retórico, se pode considerar um recurso ao serviço da credibilidade da sua exposição e, simultaneamente, comprovar que a região se mantém inalterável, continuando inóspita para o homem branco. Mas rapidamente o narrador generaliza as suas reflexões a toda a África ${ }^{16}$, recorrendo, mais uma vez, ao relatório de Julho de 1885 de W. P. Tisdel.

As notas disfóricas alusivas a África, constantes no excerto anterior, estão igualmente presentes nas referências ao seu nativo:

"não só o clima, como a selvajaria dos naturais, seria obstáculo ao estabelecimento do Europeu" (...); "as gentes do Congo são ferozes, selvagens e cruéis" (I, p.47); “- É precisamente pela razão de serem selvagens e bravos que urge primeiro que tudo pensar em submetê-los." (I, p.48)

Ressalta do vocabulário utilizado, uma apreciação subjectiva e etnocêntrica $^{17}$ do branco relativamente ao negro, visto como um selvagem. E, se não são palavras assumidas pela entidade narrativa, que se apresenta aqui como um mero relator, o seu discurso indicia o assumir de uma superioridade civilizacional/cultural. São as

\footnotetext{
16 "mas na África, onde a natureza lhe [homem branco] pôs o clima como barreira aos esforços, e circunstâncias de carácter meteorológico e telúrico, primeiro que coisa alguma, lhe quebram as forças e minam a existência;" (I, p.45); "Em África deve o Europeu residir em ponto alto..." (I, p.47).

${ }^{17} \mathrm{O}$ termo etnocentrismo "consiste à ériger de manière indue, les valeurs propres à la société à laquelle j'appartiens en valeurs universelles". Tzvetan Todorov, op. cit., p.19.
} 
considerações de um homem branco que associa civilização, progresso, superioridade à Europa, o que pressupõe não admitir estas correlações relativamente ao espaço africano, a par com o intento de "no interesse do indigena mas muito particularmente no interesse dos capitais europeus [...] submeter os habitantes do Congo e civilizá-los" (I, p. 48), isto é, obrigá-los a viver segundo os valores e a praxis sociais próprias da Europa, não valorizando, nas sociedades tribais, os seus modus vivendi como sistema diverso de organização ${ }^{18}$.

No capítulo II do mesmo volume, em estilo lacónico e incisivo, o narrador resume o carácter do Negro: "A ingratidão e a perfidia, essas torpes faculdades tão comuns nas inteligências rudimentares, formam o traço característico do Negro." (I, p.80), apoiando-se depois, mais uma vez, na declaração de um outro explorador, Stanley. ${ }^{19}$

Merecem da nossa parte uma maior atenção as expressões utilizadas para a nomeação do negro, de que são exemplos no volume I: "companheiros de cor" (p. 81); "selvagens" (p. 85 e 138); "bandos de salteadores negros" e "barbaria poligâmica" (p. 125); "Africano" (p. 138); “Negro" (p. 130); "negro" (p. 135); "infeliz das selvas" (p. 141); "nossa gente" (p. 143); "habitadores" (p.188, 207, 225, 280); "habitantes" (p. 198); "companheiros africanos" (p. 206); "coorte de ingratos" (p. 203); “o tipo negro" (p. 221); "negraria" (p. 231); "nossos companheiros" (p. 273); no volume II: "tipos" (p. 19); "indígenas" (p. 20, 105, 147 e 185); "nossos homens" (p. 26 e 113); "pretos" (p. 40 e 193); "o negro africano" (p. 48); "naturais" (p. 99 e 122); "povoadores" (p. 147 e 196); "homem" (p. 173); "o gentio" (p. 185); "nossos enfraquecidos companheiros" (p. 187); "camarada negro" (p. 199); "Negros" (p. 206).

Analisando os vocábulos designativos do habitante de África, verifica-se que o etnocentrismo patenteado pelo narrador assenta não na coloração epidérmica mas essencialmente nos modus operandi et pensanti do africano, considerando-o num patamar civilizacional muito

\footnotetext{
${ }^{18}$ Problemática mais adiante explorada com mais pormenor.

${ }^{19}$ Sir Henry Morton Stanley (Denbigh, País de Gales, 1841 - Londres, 1904) foi um jornalista que se tornou famoso pela sua viagem pela África em busca do explorador britânico David Livingstone e pelo seu papel na criação do Estado Livre do Congo.
} 
rudimentar, num estádio evolutivo muito primitivo, muito aquém do europeu.

Considerando a sua semântica, o grau mais ou menos subjetivo nelas implícitas, podemos formar grupos distintos com aquelas designações. Comecemos com as que consideramos de valor neutro, abstendo-se o narrador de the incutir a sua visão pessoal: africano, indigena, habitadores, habitantes, naturais, povoadores, homem. Outras há que têm como denominador comum a cor - Negro, negro, pretos, negraria, tipo negro, o negro africano. Algumas destas possuem já o cunho subjectivo da entidade narrativa pelo sentido de desprezo nelas vinculado: negraria cujo sufixo ganha uma valoração pejorativa ao aliar ao sentido de colectivo e de multidão, o de grupo à parte, o de sectarismo. $\mathrm{O}$ mesmo se verifica relativamente a gentio.

Numa outra classe, colocamos as designações de uma evidente e acentuada carga semântica negativa, traduzindo o desdém do narrador e, simultaneamente, a concepção preconceituosa que prevalecia então entre os europeus por certos costumes e atitudes generalizadas de algumas etnias - selvagens, bandos de salteadores negros, barbaria poligâmica, coorte de ingratos. Em algumas destas expressões, o sentido pejorativo é reforçado pela junção de dois vocábulos já de si de uma semanticidade aviltante.

Resta-nos destacar as que envolvem uma apreciação subjectiva valorativa positiva - companheiros de cor, nossos companheiros, nossos homens, camarada negro, nossos enfraquecidos companheiros enunciações referentes aos negros da expedição e pelos quais o narrador demonstra apreço, afecto e aceitação, não só evidente no significado dos vocábulos $\operatorname{citados}^{20}$, mas também pelo junção do determinante possessivo nosso(s), de valor inclusivo, de pertença ao grupo.

\footnotetext{
${ }^{20}$ Etimologicamente o termo companheiro provém de companha (do latim cum+panis), aquele com quem partilhamos o nosso pão. Camarada, de origem italiana, é o companheiro de casa, o que nos é íntimo.
} 
Também a expressão infeliz das selvas, por via de uma derivação imprópria (adjectivo substantivado), prova a empatia do narrador face ao outro. O mesmo se pode afirmar quanto à grafia dos vocábulos "Negro" e "Africano" com maiúscula, sem que as normas gráficas assim o exijam ${ }^{21}$.

De realçar que estas expressões vão sendo mais frequentes à medida que a viagem progride e as adversidades se acentuam, o que favorecerá a aproximação dos seres, a solidariedade e a compreensão de África, dos autóctones e dos seus modos de agir, por parte do homem branco, tal como veremos mais adiante.

\section{Referências à indumentária e aos costumes}

Vejamos o que se diz acerca dos trajes masculinos:

Um sórdido pano na cinta, [...] e um molho de amuletos, paus e búzios ao pescoço, juntos a fiadas de missanga, constituem a suprema distinção. // A sua pele é extremamente retinta, untam com manteiga os cabelos, [...] amassando-os por maneira que o penteado parece uma verdadeira cabaça! (I, p.88)

Nada há mais abjecto e repugnante do que esse arremedo de homem, que hoje vagabundeia pelos bosques e campinas do grande continente [...]. Tão revoltante é esta raridade do humano género, tão mesquinho o seu ar, apoucado o vulto e estranho o modo, que degrada e aflige ter que descrevê-lo. // É como se defronte de nós se erguera um cadáver, [...] o seu aspecto é repelente.

(I, p. 158)

[...] têm repelente aspecto, limam em ponta os dentes e fumam de contínuo por narguilés feitos de pequenas convulváceas. (I, p. 309)

Pelo geral estes povos [Mambundas] [...] se em seu todo há o que quer que seja de asselvajado, concorre para isso o modo como se adornam e penteiam. // Peles de cobra enroladas ao pescoço, donde pendem dentes e garras de leão; grossas tranças dispersas na cabeça em todos os sentidos, dando-lhes por vezes aspecto de medusas; enorme faca à cinta e uma cauda de gnu pendente do

${ }^{21}$ Sem obliterar, contudo, que se recorre a este procedimento quando se designa globalmente um povo ou uma etnia, situação também aqui importante. 
lado, não podem formar um conjunto que os torne atraentes. (I, p. 244)

Povo [...] parece, sem ser extremamente feroz, ter hábitos assaz primitivos, pois todos vestem uma pequena pele, usam zagaia [...] usam puxar o cabelo todo para o alto da cabeça e, à medida que este vai crescendo, vão-no emendando e torcendo, à feição de rabicho, com azeite e manteiga, chegando a atingir um comprimento exagerado. Pela noite sobretudo vêem-se embaraçados para acomodar tal topete, tornando-se necessário a esposa, após deitado o marido, amarrar-1he o extremo da trunfa ao tecto da casa! Que original! (II, p. 194)

Destes excertos transparece um julgamento assaz depreciativo. Concorrem para esta leitura não só o vocabulário como também a utilização de certos recursos estilísticos como a repetição do advérbio de intensidade "tão" - “Tão revoltante [...] tão mesquinho" — I, p. 158; expressões comparativas - "o penteado parece uma verdadeira cabaça!" - I, p. 88; "É como se defronte de nós se erguera um cadáver" — I, p. 158; exclamações que traduzem a ironia: "Que original!" - II, p. 194 - ou a censura do narrador face ao descrito: “amarrar-lhe o extremo da trunfa ao tecto da casa!" - II, p. 194. Veja-se também a adjectivação irónica presente na expressão "suprema distinção" - I, p. 88.

O aspecto físico das mulheres merece igual tratamento, observando-se, inclusivamente, em algumas passagens, uma crítica mais exacerbada. Por norma, é no exagero, na matéria e origem dos adornos, que recai a depreciação descritiva.

Uma rapariga [...] com o cabelo dividido em tranças carregadas de missanga, e que, não contente com isso, trazia ao pescoço monumental colar do mesmo artigo, adicionando, para agravar este peso, um cinto de grossas contas, e tudo untado e a escorrer em manteiga de vaca! // Entre os amuletos que [...] trazia ao pescoço, notámos uma fechadura de baú e uma unha de porco, sem contar outros artigos miúdos de dúbia proveniência! // As mulheres são em geral formosas, mas sórdidas, o que é agravado ainda pela aludida untura de manteiga. // Limam ou partem os incisivos médios de cima; uma espiral de ferro de 30 centimetros [...] enfeita-lhes as pernas e braços [...] usam de uma infinidade de bocados de latão, chapas de cobre, enfiadas de sementes, etc. (I, p. 150) 
[...] os cabelos da velha, que, escorrendo gordura e enfeitados com cânulas de porco-espinho, lhe davam o aspecto de um ouriço; enquanto no pescoço emagrecido um formidável quisto sebáceo, aneurisma ou o que fosse, se movia à mercê do músculo, mais próximo, atropelando um colar de contas e chifres de antílope, e os seios, estirados na direcção dos graves, oscilavam pendentes e graciosos em busca da normal! [...] // A repelente velha [...] acocorou-se. Um trapo imundo, como defesa do casto pudor dessa diva, caía por diante até aos nodosos joelhos, que, cansados de suportar (ao que parecia) tanta sordidez, estavam dispostos a fugir de entre fémures e tíbias! (I, p. 216)

Mais uma vez se observam descrições sensoriais, imbuídas de subjectividade, com a presença dos recursos estilísticos já aludidos - a ironia ("diva"; "joelhos, que, [...] estavam dispostos a fugir de entre fémures e tíbias!”; “um formidável quisto sebáceo”) e os comentários do narrador.

A mulher bushmen, dada a sua configuração física, é a que surge referida com maior repugnância - no dizer do narrador, um ser aviltante, um escárnio à espécie humana. Repare-se nos vocábulos sublinhados e no humor irónico da última frase:

A cor amarela da pele [...], a sua pequena estatura, os traços repelentes do rosto, o aspecto de decrepitude prematura, a fatal e constante miséria, tornam ainda a mulher bushmen, vítima desta deformidade [esteatopigia] mais hedionda, segundo julgamos ${ }^{22}$, que a hotentote. // Vis arremedos da espécie humana, esses indescritiveis seres parece que foram muito de propósito arquitectados para permanente insulto à plástica! (I, p. 190)

Não podemos ignorar alguns reparos de cariz humanista sobre a condição da mulher africana, em algumas tribos, fomentados pela ética europeia.

Para essa infeliz há na terra apenas os labores, as proibições e o esquecimento, ou antes, o desprezo na velhice! [...] É uma vida de misérias e prepotências, onde a fraqueza caminha, subjugada, sem murmúrio, à mercê da vontade do forte; [...] Como o cão, ou qualquer outro animal doméstico, o seu lugar é quase sempre junto à palhota! (I. p. 291-292)

22 A parcialidade da visão que é transmitida pelo narrador é consciente como o demonstra este aposto. 
Quão infeliz é a mulher por estas terras, e pequena a estima que o rei da criação aqui tem pela sua dedicada companheira! (II. p. 60)

A deferência e a compaixão aqui expostas são também dirigidas às mulheres ${ }^{23}$ que seguem na caravana, louvando a sua fidelidade ao parceiro, o seu espírito de sacrifício e o zelo pelos filhos em nada inferior à "elegante habitadora do bulevar" (II, p.168).

A estranheza, o absurdo, a incompreensão e o ridículo são ainda notados quando o narrador se refere aos costumes ${ }^{24}$ - "Rolam-se de costas perante o soba e, batendo as palmas, operam com os lábios um som semelhante àquele por nós produzido para chamar os pintainhos" (II, p. 147); a práticas rituais ${ }^{25}$ ou às crenças, retratando os n'gangas ou adivinhos, por norma, como personna non grata: "valendo-se da cegueira dos seus conterrâneos, cometem toda a casta de extorsões e de infâmias!"; "Estas criaturas exercem o seu maléfico oficio por diversos modos" (I, p. 130-131); - "Pasmávamos do quanto pode a superstição e a ignorância num cérebro mal alumiado pelo juízo" (I, p. 130). As suas habitações merecem igual apreciação pejorativa - I: "sórdidas habitações" (p.148); "míseras cubatas" (p.159); "miseráveis senzalas" (p.264) e "miseráveis habitações" (p.287).

Mas, concomitantemente com estas descrições e opiniões marcadas pela subjectividade madrasta ${ }^{26}$, encontram-se relatos favoráveis sobre algumas tribos: os dos Banhanecas (I. p. 137), os

\footnotetext{
${ }^{23}$ II, p. 168.

${ }^{24}$ Leia-se em pormenor as referências às festas da hela (I, p.153-154), do Gongo, do mantimento e da chuva (I, p. 167-168); a cerimónia da troca de sangue (II, p.40-41), as referências ao adultério encarado como um negócio pelas tribos do Sul e margens do Zambeze (I, p.88-89), as considerações gerais do narrador no vol. II, p.82 e 248 onde se descreve um costume dos Jagas: "Bem estranhos eram os seus costumes".

${ }^{25}$ Veja-se as cerimónias fúnebres dos Bacorocas (I, p. 89) e dos Bancúmbis (I, p.168169)

26 I, p.227-229, o narrador generaliza as suas considerações, referindo-se "colectivamente" aos negros. Nestas páginas são apresentadas as características físicas comuns, afirmando-se que são "constantes no seu modo de ser e operar, têm norma e vida tão primitiva e organização de sociedade tão singela e geral” (p.227). São proferidas asserções marcadamente preconceituosas e etnocêntricas, como a comparação física ao macaco e o "contraste estranho!" com as "belas figuras da Grécia”.
} 
Bancúmbis (I. p. 166), os Amboelas, "os pretos de melhor aparência que temos encontrado" (I. p. 198), os Baiaumas (I. p. 250) e os Morozes (I. p. 287). Analisando o que se afirma sobre estes grupos, somos levados a crer que a apreciação é agora mais favorável pelo facto dos seus modus vivendi serem sustentados por valores também apreciados $\mathrm{e}$ incentivados no espaço de origem do narrador: o valor do trabalho, o acumular de bens, a organização social (divisão de tarefas) e o gosto estético:

Os homens empregam-se em apascentar os rebanhos, cortam madeiras e desbastam mata; os rapazes mungem as vacas e preparam a manteiga e o leite coalhado [...]; as mulheres amanham as terras e [...] fazem as sementeiras

(p. 166)

[...] pescadores na maior parte e perfeitos marinheiros. Em suas longas pirogas, munidos sempre de fisgas e zagaia, operam prodígios de evolução e rapidez, deixando-nos maravilhados com tais exercícios [...] (p. 287)

As mulheres desta aldeia gostam muito de música, mas principalmente da dança. Possuem um talento estranho na apreciação da harmonia, executando coros com proficiência notável, e sobretudo desusada extensão. [...] trechos de canto agradáveis e suaves, inspirando [...] uma emoção a que estávamos longe de nos supor acessiveis no âmago dos sertões africanos [...] (p. 267)

Tais passagens são, portanto, uma excepção à apreciação geral que o narrador faz acerca do negro: "o Negro é a expressão embrionária do sentimento, e na sua rude incompreensão do dever e da dignidade faz parênteses em quase todos os princípios da nobilitação humana." (I, p. 203). Com efeito, já anteriormente tinha afirmado que

Permitir-lhe [ao negro] a vadiagem é deixá-lo contrair na ociosidade repugnantes vícios, que pouco a pouco originam crimes; e querer depois castigá-lo com a aplicação do código penal do reino, que ele não compreende, nem sente, nem o molesta, garantindo-lhe [...] o alimento no caso da prisão (seu sonho dourado, comer sem trabalhar), torna-se numa verdadeira calamidade.

(I, p. 141)

Fica então demonstrado, mais uma vez, que o sujeito narrativo descreve os povos africanos e tece considerações sobre eles à luz do 
referencial valorativo europeu, resultando numa visão preconceituosa e subjetiva, porque incapaz de se distanciar do seu quadro ético e lançar sobre o outro um olhar objectivo, neutro.

\section{Quando as condições da viagem se agravam}

Detenhamo-nos, doravante, nos reveses que, aos poucos, vão tornando a viagem sobremaneira espinhosa, tópico que se vai convertendo numa obstinação à medida que as complicações aumentam e se sucedem.

Aos primeiros rigores do clima (I, p. 111) — "transudando sob um sol de escaldar, sofrendo as cruéis impressões do tirocínio" - acrescemse outros obstáculos: as peculiaridades geográficas, as fugas dos carregadores, a perda de bens, a urgência em reduzir a bagagem, cortando no conforto (I, p. 146 e 205) e, sobretudo, a fome:

Activadas as funções vitais por um exercício exagerado que a temperatura, as águas, etc., exaltam, anda o viajante sempre sob a impressão de uma ameaça de fome, que lhe orvalha a boca de água ao antegostar na imaginação um prato que a necessidade lhe pinta como muito saboroso. A mingua de distracções de espírito, torna-se mais imperativo o gozo material de encher o estômago, aprecia mais essa ideia, domina-o grosseiramente o desejo sensual de ingerir o que vê, trazendo sempre interessado o receio das faltas frequentes. (I, p.156)

Esta é pois “o terror do sertão" (I, p. 181), uma das principais causas das mutações experimentadas pelo homem, africano ou branco. Eis alguns exemplos.

Quereis vê-lo, errante e desvairado, os membros nus e emagrecidos, a pele do ventre rugada, deprimida em concavidade, divagando com o olhar emparvecido por entre a floresta em procura de qualquer coisa que lhe mitigue a fome, volvendo-se ao menor rumor onde supõe existir um réptil, [...] indiferente aos vossos clamores, abandonando carga e companheiros, para vaguear em matos onde fatalmente tem de perder-se; (I, p.182)

[...] indo os bois a diminuir rapidamente, a negra imagem da fome começava a erguer-se ante nós, facto gravíssimo, que não sabíamos como remediar [...]. O nosso desânimo ainda 
aumentava ao presenciarmos a aridez do solo, que pela sua natureza estéril pouco nos poderia fornecer. (I, p. 209)

A caravana tornara-se agora num bando de salteadores, e pela noite, abalando pelo escuro, lá foram numa razia roubar quanto encontrassem, sem que nós tivéssemos a coragem de os impedir. (I, p. 216)

Assaltando os indigenas que encontrávamos carregados com a cocha, avançávamos debaixo de água até ao rio Mutanda [...], cheios de fadiga, de desgosto e de parasitas!" (II, p. 20)

Ao testemunhar uma cena de antropofagia, o narrador, ao invés de a recriminar, o que seria coerente com as suas iniciais apreciações sobre o africano, é levado agora a refletir sobre as suas causas, declarando que o homem é capaz de tudo em determinadas circunstâncias.

Nós mesmos, de há muito habituados a estas cenas, quando a meio deste movimento atentávamos nos actos dos nossos companheiros, e éramos testemunhas da ânsia selvagem com que estes esbrugavam a apófise de um fémur, e aquele devorava sôfrego os tendões agarrados a uma tíbia, não podiamos deixar de reflectir quanto o homem se rebaixa ao nivel da animalidade sempre que a falta de recursos o obriga à luta para alimentar-se; e quanto o infeliz perde da superioridade e se apresenta aos olhos do investigador como o mais vil desprezivel dos irracionais. (I, p. 267)

Sofrem ainda outras adversidades: a falta de água potável (I, p. 206), as moscas e os mosquitos que levam à morte os preciosos boiscavalos (I, p. 281), as pragas das moscas tsé-tsé (II, p. 30-33), as doenças, como o escorbuto (II, p. 155) e as mortes (II, p. 273) humanas e dos animais ${ }^{27}$.

É clara a marca dilacerante no discurso narrativo aquando das alusões às carências sofridas pela caravana, disforia que é acentuada pela repetição deste topos.

O desespero tem, como efeito imediato, o enfraquecimento do espírito dos viajantes e a consciencialização da urgência em se

\footnotetext{
${ }^{27}$ Os bois-cavalos eram preciosos para o sucesso da empresa e para a sobrevivência dos viajantes, pois serviam de meio de transporte e eram abatidos quando não havia outro alimento disponível.
} 
adaptarem às novas realidades: abandonam as tendas e passam a dormir "à moda indígena” ou "à la belle étoile” (I, p. 289).

Face à experimentação de novas situações, à premência em se ajustar às contingências do meio, o homem branco começa a ter uma outra percepção da realidade e, ele próprio, toma noção das transformações que em si se estão operando: “o carácter do indivíduo perverte-se [...] o homem enfim é outro!” (I, p. 214).

Nada se pode imaginar de mais cruel do que as angústias experimentadas por esse sertão [...]. // Se nos fora lícito bem atentar no nosso profundo desgosto e abatimento moral, veríamos que somos outros, e que o isolamento e os obstáculos, tendo varrido da memória [...] necessidade de uma energia obstinada, nos tornaram meio selvagens, identificando-nos com o modo de ser de quanto nos cerca e em que nem um só delicado sentimento tem ensejo de manifestar-se. (II, p. 22)

Eis aqui explícito que "somos outros", que o estado de espírito do narrador já não é o mesmo. Sente-se agora identificado com o espaço trilhado. Comprova igualmente esta mudança, o reconhecimento dos riscos e do incómodo das tendas e a confissão da superioridade da "barraca de folhas à moda africana" (II, p. 25) onde se goza "de um relativo descanso, sem receios nem humidades" (II, p. 26).

Também agora o narrador está em condições de apreender com outro olhar o que o cerca e, perante o isolamento a que está votado, estão reunidas as condições para "embrenhar-se nas profundezas da sua alma e, de escalpelo em punho, [...] fazer estudo anatómico do espírito, que o leva a entrever perfeições ou corrigir defeitos que até ali ignorava." (II, p. 26).

O espectáculo tranquilo e atento das maravilhas da natureza também concorre para lhe sublinhar os sentimentos e, meditando na grandiosidade do que o cerca, e arrastado a melhor compreensão do belo e do imenso, assim como o consequente enobrecimento do próprio sentir e surpresa do seu poderio.

(II, p.26)

Esta propensão para um olhar diferente sobre um meio estrangeiro mas que agora partilha, permite-lhe evocar momentos venturosos ali vividos e afirmar que, “embora longe e isolados, éramos 
bastante superiores e felizes, para poder admirar tamanhas e tão numerosas maravilhas!" (II, p. 28). É esta nova predisposição que explica, em parte, a problemática do conhecimento científico versus o adquirido pela experiência/prática ${ }^{28}$. Sobressai, a partir de um certo momento ${ }^{29}$ da narrativa, a valorização da experiência em detrimento do saber científico: "Nem pio! Toda a nossa ciência de marinheiros caía perante a experiência de dois negros de longas pagaias ${ }^{30}$ em punho." (II, p. 146); "O hábito do mato, porém, ensina a marchar pelo solo balofo e lodoso em que este assenta, não devendo o viajante pôr o pé à toa quando marcha" (II, p. 162).

Diríamos então que o homem branco que chegou à África, de olhar formatado pela ordem moral europeia, não é o mesmo que regressa à Europa. As experiências obrigam-no a comungar do ser africano e contribuíram para a sua mudança. Vendo e entendendo a África não de fora mas de dentro, regressa a casa um outro homem, mais conhecedor de si próprio e do outro.

\section{Conclusão}

Do exposto retiram-se algumas considerações sobre o modo de descrever o "outro", o seu espaço e o seu modus vivendi.

Verifica-se, sobretudo na fase inicial da viagem, quando os problemas ainda não se tinham evidenciado em toda a sua dimensão, que a visão do narrador está afectada claramente pelos seus cânones culturais, originando descrições e opiniões egocêntricas, inquinadas, o que, segundo Todorov, é uma atitude naturalmente humana (cf. página $3)$.

Porém, a mudança no modo de ver e percepcionar o outro acontece. O olhar, no início, tendencialmente míope, torna-se mais

\footnotetext{
${ }^{28}$ Lembramos que, subjacente a estes dois modos de conhecimento, está a dicotomia Europa-África.

${ }^{29}$ Quando o homem, por influência das adversidades, se tornou num outro: II, p.22.

30 Termo africano para designar um remo de pá larga e haste curta.
} 
indulgente à medida que o narrador, sofrendo a influência do meio, aprende a relativizar, o que lhe possibilita uma maior e melhor compreensão e entendimento do africano ${ }^{31}$. O conhecimento do outro só foi possível porque houve uma predisposição do eu para dele se aproximar e o compreender no seu contexto histórico, geográfico e ético.

De acordo com a teorização de Jean-Jacques Rousseau, esta abertura deveu-se a circunstâncias externas: a experienciação do viver em África. Contactando, por um longo período de tempo, com o meio e os outros, o entendimento do narrador tornou-se permeável à realidade exterior. Foram as circunstâncias que aproximaram o eu do tu, dando origem a uma identificação, traduzida repetidamente por um nós (inclusão no mesmo grupo). Já Rousseau chamava a atenção para os poderosos efeitos da diversidade climatérica, do ar, da alimentação, da maneira de viver, dos hábitos em geral, sobre a espécie humana, sobretudo quando agem durante longos períodos ${ }^{32}$.

Podemos então considerar que esta viagem de exploração se transformou numa viagem iniciática ao serviço do autoconhecimento, por ser o motor propulsionador que desencadeou um viagem intima, que evoluiu em espiral, em direcção a um conhecimento mais profundo do ser, graças a uma realidade exterior que lhe era inicialmente estrangeira. O eu assimilou e aceitou a diversidade de ser, de estar e de pensar.

Podemos inclusivamente verificar que, em certos momentos, se deu uma assimilação cultural. É o que se verifica com a noção de tempo. Muito valorizada pelo europeu e que "parece nada valer para o africano" (II, p. 61), perdeu, também, para aquele, todo o sentido: "Estávamos uns perfeitos régulos africanos, indiferentes ao tempo e inclinados ao pasmo" (II, p. 154).

Julgamos importante sublinhar que a identificação e empatia do narrador com o espaço africano se diluem à medida que se aproxima a

\footnotetext{
${ }^{31}$ Sylvie Requemora, "L'espace dans la littérature de voyage", p.269-276.

32Jean-Jacques Rousseau, "Discours sur l'origine et les fondements de l'inégalité parmi les hommes", p. 208.
} 
hora do regresso a casa, quando deixa o chão africano e embarca no navio.

Estávamos perante homens afeitos ao viver das selvas, únicos capazes de compreender e apreciar o que por lá se passa, a quem apraz dizer e contar, na certeza de que se é entendido, enquanto as damas e os engravatados senhores que na tolda do navio escutam a narração da mais singela peripécia são auditores indiferentes (II, p. 208)

Estava por assim dizer terminada a nossa missão; as selvas, os matos, as feras, a fome, tudo havia terminado como por encanto, de um passo estávamos cercados de compatriotas, imersos num mundo meio civilizado [...] tivemos um assomo de saudade das selvas do Lualaba. // Pouco a pouco nos habituámos. O pensamento e o brilho da civilização europeia começaram de exercer em nós a sua fatal influência, arrastando-nos [...]. (II, p. 215)

Daqui se infere que o meio exerce um poder fatal de modelação sobre os indivíduos que dele fazem parte. Demonstra também uma qualidade exemplar do ser humano, responsável pela sua sobrevivência ao longo dos tempos - a capacidade de adaptação.

Chegando ao fim da nossa análise, julgamos ter focado os tópicos aludidos no plano inicialmente exposto. Demonstrou-se que o homem, sendo um ser social, tem imbuído no seu eu um conjunto de valores preconizados pelo seu meio e que, sub-repticiamente, moldam a sua cosmogonia. Logo, ele tem que ter consciência desta realidade para aceder ao conhecimento dos outros que habitam em espaços diferentes e distantes do seu, sem cair no erro de os julgar à luz dos seus princípios. Também ficou explícito que todos os seres humanos partilham da mesma natureza intrínseca a qual emerge, voluntariosa, nos momentos de crise. Se a civilização tende a abafar, no dia-a-dia, os instintos mais primários do ser humano, estes despontam mal a sobrevivência é posta em causa ${ }^{33}$.

33 [...] esquecêramos tudo ante a asselvajada ânsia de encher o estômago, positivamente animalizados, não diferindo em coisa alguma o nosso modo de pensar do de qualquer companheiro indígena. (II, p. 135) 


\section{Referências bibliográficas}

CAPELO, Hermenegildo e IVENS, Roberto. De Angola à contracosta. vol. I e II. Mem Martins: Pub. Europa-América, 1998.

CARVALHO, Alberto. "Estética, ciência e estética do olhar na viagem de Capelo $\&$ Ivens" in O olhar do viajante. Coimbra: Almedina, 2003.

Dicionário enciclopédico Alfa. Lisboa: Publicações Alfa S.A., 1992.

GANNIER, Odile, La littérature de voyage., Paris: Ed. Ellipses, 2001. (Col. Thèmes \& Études)

GARRETT, A. Viagens na minha terra. Realização didáctica Luís Amaro de Oliveira. Porto: Porto Ed., 1983.

GROUX, Dominique et PORCHER, Louis. L'Altérité. Paris: ed. L'Harmattan, 2003.

MERLEAU-PONTY. "Autrui et le monde humain" in Phénoménologie de la perception. Paris: Gallimard, 1945. (Col. TEL)

REQUEMORA, Sylvie "L'espace dans la littérature de voyage" in Études Littéraires, vol.34, n. ${ }^{\circ} 1-2$, hiver 2002.

ROUSSEAU, Jean-Jacques. "Discours sur l'origine et les fondements de l'inégalité parmi les hommes" in OEuvres Complètes III, , Paris, Ed. Gallimard, 1964. (Bib. de la Pléiade NRf)

TODOROV, Tzvetan. Nous et les autres: la réflexion française sur la diversité humaine. Paris: Ed. Seuil, 1989. 